\title{
The Toy Piano Is Not a Toy
}

\author{
Antonietta Loffredo
}

Istituto Comprensivo Statale Cernobbio I Italy

\begin{abstract}
: this paper describes a two-day composition workshop dedicated to the toy piano held in 2019 at a state middle school with a musical address in Italy. Eight young pupils in the early years of their piano studies took part. The resulting compositions are shown and indicate that the toy piano is a useful means to stimulate creativity in young pupils. A further consideration addressed is that operating in the educational field means expanding the future audience with respect to new musical languages and means of musical expression. In discussing both pedagogical practise and composing and performing, the author's aim is to contribute to the comprehension of the 'toy piano phenomenon' which in recent years has increasingly seen this instrument take centre stage on the contemporary music scene.
\end{abstract}

Keywords: Toy Piano, Music Composition, Creativity, Contemporary Classical Music, Pedagogy. 


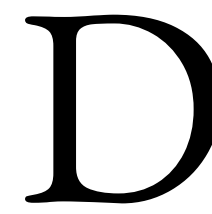
escribed by performer and composer Elizabeth A. Baker (2016, p. 4) as a 'valuable teaching instrument' and educational tool when introducing piano studies, my opinion of the toy piano in this role is somewhat critical. From experience, I have found the differing weight and dimensions of the keys, the required posture, unpredictable overtones, limitations in dynamics and imperfect pitch (at least in the models with metal rods, usually played in public by professional musicians) to be problematic. But useful elements can be found by asking the following questions: might the 'imperfect' sound and limitations of the toy piano enhance creativity in young pupils? Could the toy piano serve young musicians to give direction to their imagination? The answers are positive with regard to the adult performing world, testified by an increasing interest towards the toy piano in contemporary classical music. Outcomes are less evident when referring to young pupils and the toy piano, and this needs further investigation. In this paper, I will discuss the two questions posed above from a pedagogical point of view, through observations conducted during a workshop entitled Seriously or Jokingly? Toy piano composition workshop for early stages held by Spanish composer Mercedes Zavala ${ }^{1}$ as invited professor to the state middle school where I teach piano. The steps of the two-day workshop will be described and excerpts of the resulting compositions shown and discussed. Finally, my experience report will be the starting point for personal considerations on the toy piano phenomenon in the light of its current musical status and future performance, teaching and composition perspectives.

\section{The two-day workshop}

Eight of my students (aged 11 to 12 years), at the beginning of their piano studies, were invited to compose short toy piano pieces under the guidance of composer Mercedes Zavala. My role during the workshop was that of facilitator (being the piano teacher of the pupils involved) and observer. None of the pupils knew this instrument, except for one of them and, in this sense, the toy piano can be considered for most of them an 'object trouvé', to be discovered and explored.

\footnotetext{
${ }^{1}$ Mercedes Zavala studied piano and composition at the Madrid Music Conservatoire. She has been a pupil of Malcolm Singer, a main figure in her development as composer and teacher. In 1997 she graduated in Philosophy. In the 2000s she worked for Radio Nacional de España and was President of Spanish Women in Music Society. Nowadays Mercedes Zavala teaches music composition at Madrid Conservatorio Teresa Berganza. Within her nearly 90 works, there are chamber and orchestral works, pedagogical works, an occasional musical theatre work, and there is the persistent influence of literature.
} 
On the first day, we introduced the toy piano giving particular attention to the sound and how it is produced, and on the performance possibilities of the instrument. We then invited pupils to play some pieces from their repertoire at the piano. Zavala followed, asking questions to the students so they could focus on some simple elements as a useful input to start the composition phase. Her guiding idea at this step is that resource limitations are convenient in the early stages of composition and the toy piano can be, in this sense, a facilitator. Zavala says:

The choice of the toy piano favours some aspects that help the initiation to compose. At this student level, to compose means a change of perspective, a step to another way of understanding music, indeed a passage to another musical reality. The toy piano is a new instrument for all of them, so they have to do prior work of exploration to understand how that new instrument works, and they have to react to its sound and possibilities; but at the same time it is a familiar instrument [since it's a keyboard instrument], so they can manage it very well. Also, it has a restricted range of possibilities that makes the writing easier. Last, but not least, the toy piano is freed from the sometimes-overwhelming weight of the music repertoire of the past. This gives the act of creating music a playful aspect, outside the overwhelming responsibility that the concept of composing sometimes implies. (ZAVALA, 2019, p. 21).

Primary elements used during the execution/listening/analysis initial phase are discussed. At first, the Gavotte HWV 491 in G major by G. F. Handel was played. Mercedes asked pupils how many voices they listened to and they identified two lines, characterised by patterns of quavers in the right hand against 'slower' crotchets at the left hand. The second piece (Fig. 1) was Bagatella Balcanica (Balkan Bagatelle), taken from a collection of easy piano pieces by Denes Agay (2010, p. 42).

Fig. 1 - Excerpt from Balkan Bagatelle, measures 1-8.
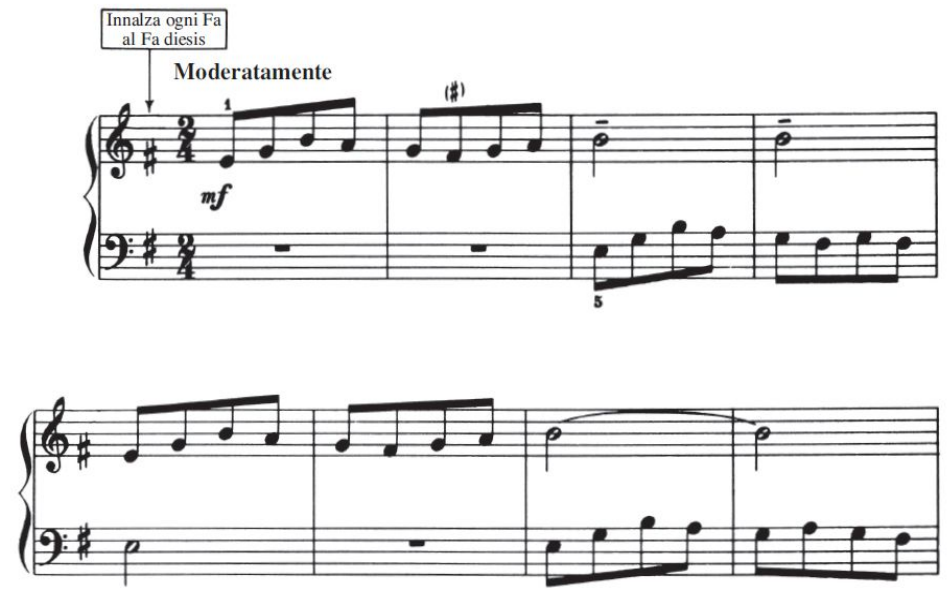

Source: AGAY (2010, p. 42) La gioia del primo anno di Pianoforte

(Courtesy Edizione italiana @ 2010 Volontè \& Co. s.r.l. - Milano/Hal Leonard s.r.l. Europe) 
Pupils grasped the following basic elements: questions and answers; a voice speaks and the other one is silent (with rests) then replies; a voice speaks loudly and the second one speaks softer. The third piece (Fig. 2) was a study by J.B. Duvernoy (1903, p. 3). Here pupils observed how long chords accompany waves of notes above.

Fig. 2 - Excerpt from Elementary Studies Op. 176 n. 1, measures 1-10.

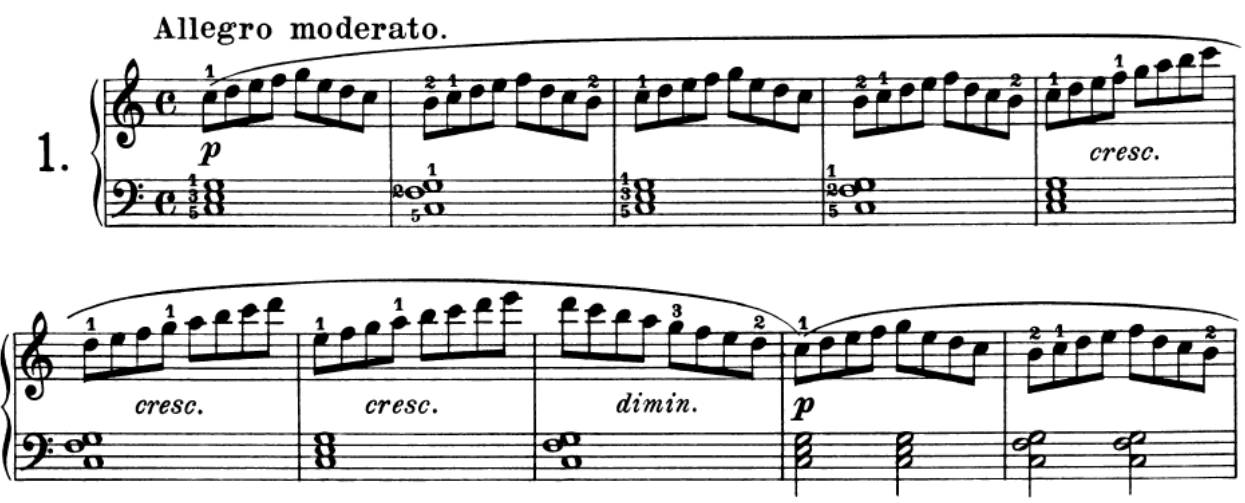

Source: DUVERNOY (1903, p. 3)

Shortly after, the composition phase began. Pupils were invited to work in pairs, on the basis of collaborative learning strategy and my previous school teaching experience with them, balancing pupils' bonds of friendship with their different individual skills. We assigned a classroom to each couple, spaces familiar to them and sufficiently isolated to allow maximum concentration. They had at their disposal pencils, papers (no music notation software) and a toy piano, and Zavala and I moved from class to class to supervise the works. The pupils' task consisted in trying to write some music, starting from the few elements initially identified; specifically, to compose using the musical resources acquired, and in a language they know. The texture of the pieces intuitively analysed would provide models to start from, but Zavala made it clear to pupils they were free to introduce variations and innovations.

On the basis of the initial assumption that less material makes it easier to handle, the pupils' toolbox contained few but essential elements, which Zavala further summarised to them: "you have listened to works with a melody in one hand and an accompaniment in the other; sometimes the accompaniment comprises repeated notes; sometimes there is another melody in the bass; now and then both hands play independently, or they alternate; somewhere one hand repeats what the other one has previously played, ...”. Thanks to Zavala's guidance in suggesting how to develop their 
initial ideas and how to represent them on paper as precisely as possible, pupils finished their pieces by the beginning of the next day, and we asked them to give a title to their works. ${ }^{2}$ The reasons behind the choice of the composition titles indicate another composition impetus. While looking for a title was an interesting step that further stimulated pupils' creative and imaginative thinking, in most of the cases it also indirectly illustrated (and guided) the compositional process they carried out.

The first couple (pupils 1-2) took inspiration from a poster hung on the wall, entitled Il linguaggio segreto delle piante (The Secret Language of Plants), which resulted in The Secret Language (Fig. 3). Keeping only what was useful to their task, they established a link between the title of the piece with the structure of their composition (intended for two performers) pointing out that when they played, it was as if they were talking to each other.

Fig. 3 - Il linguaggio segreto (The Secret Language).
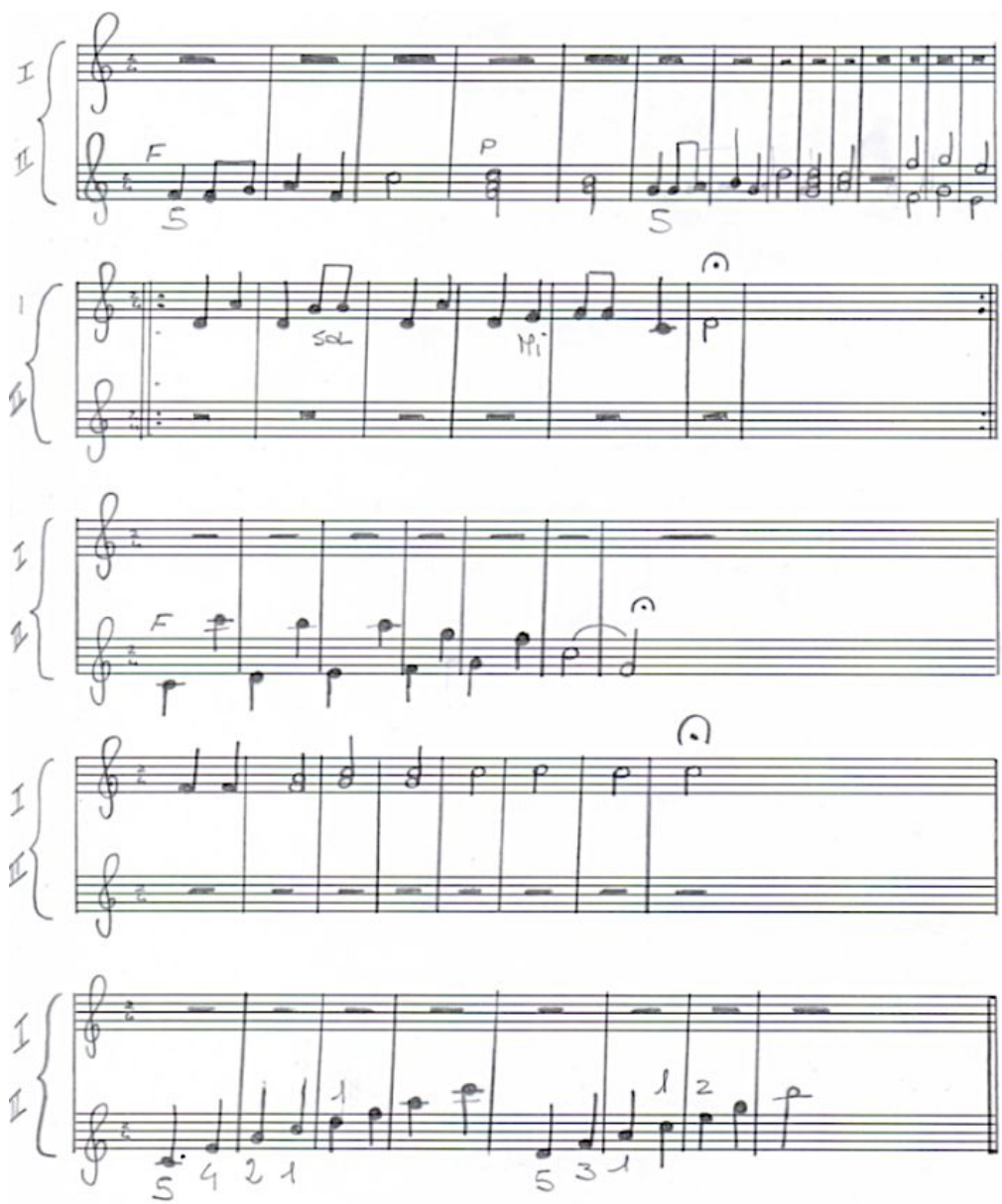

${ }^{2}$ All the pieces have been then performed at the "Music as Play. The toy piano takes the stage" festival, held in Como on the 6-7 July 2019. <https://music-as-play.wixsite.com/toypiano> 
The composers (pupils 3-4) of the second piece (Fig. 4) were motivated in their choice of the title La danza del mare (The Dance of the Sea) because "the melody goes up and down, like the waves of the sea”, once again establishing a link between title and the movement of the sea and key characteristic of their composition.

Fig. 4 - La danza del mare (The Dance of the Sea).

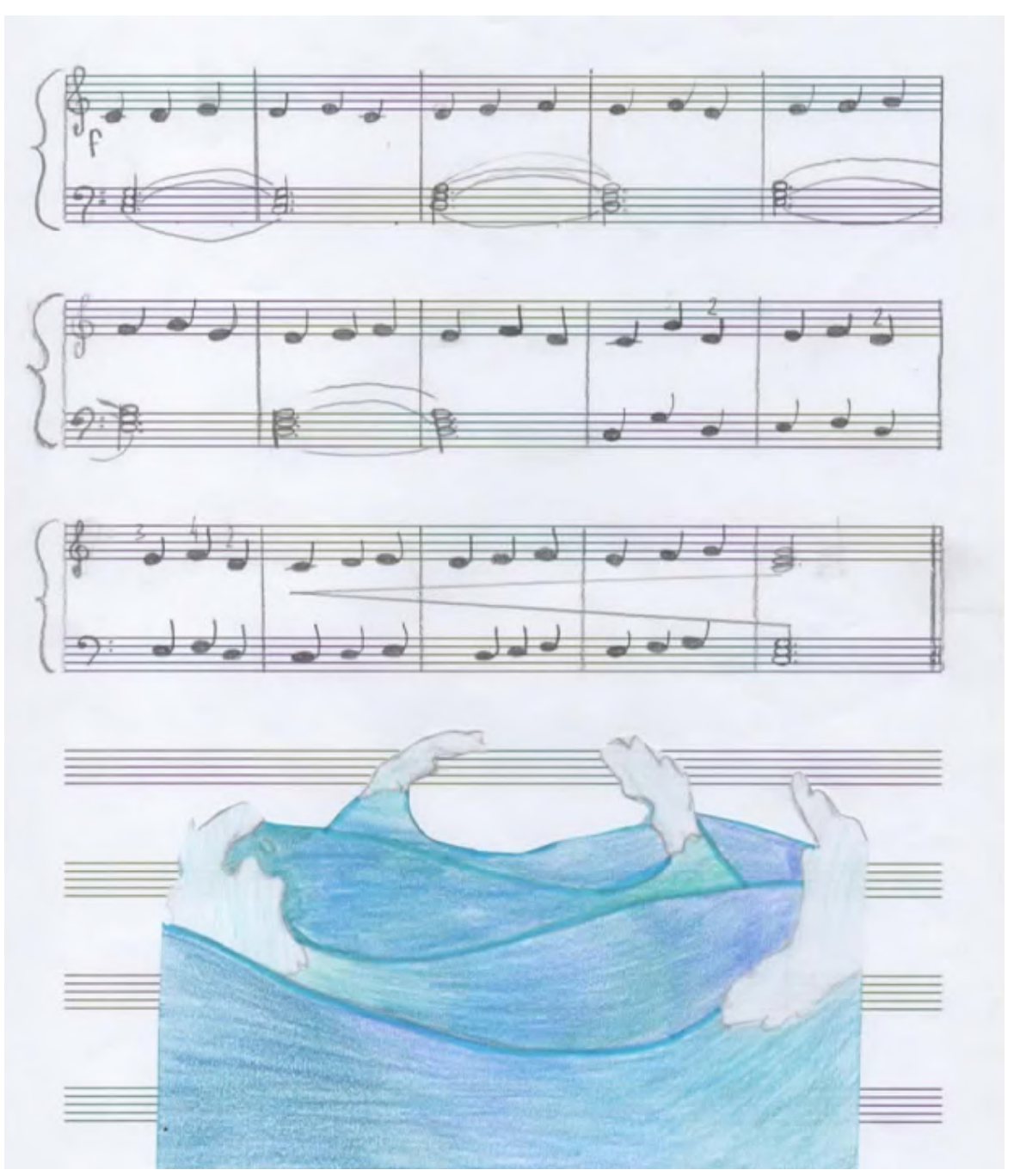

For the third piece (Fig. 5), and in the pupils' words (pupils 5-6), the title Notte stellata (Starry night) was because "the toy piano has a 'metallic' timbre and so its sound looks like stars appearing in the sky”. It is worth noting the rhythmic approach in this work as what at first might look like a writing error was instead an uncomplicated way to write a more complex rhythmic barring. At first, it was not clear what the composer pupils wanted from a metric point of view but after asking their 
intentions, pupils played the piece, and it was clear what they wanted - mixing common and irregular meters.

Fig. 5 - Notte stellata (Starry Night).
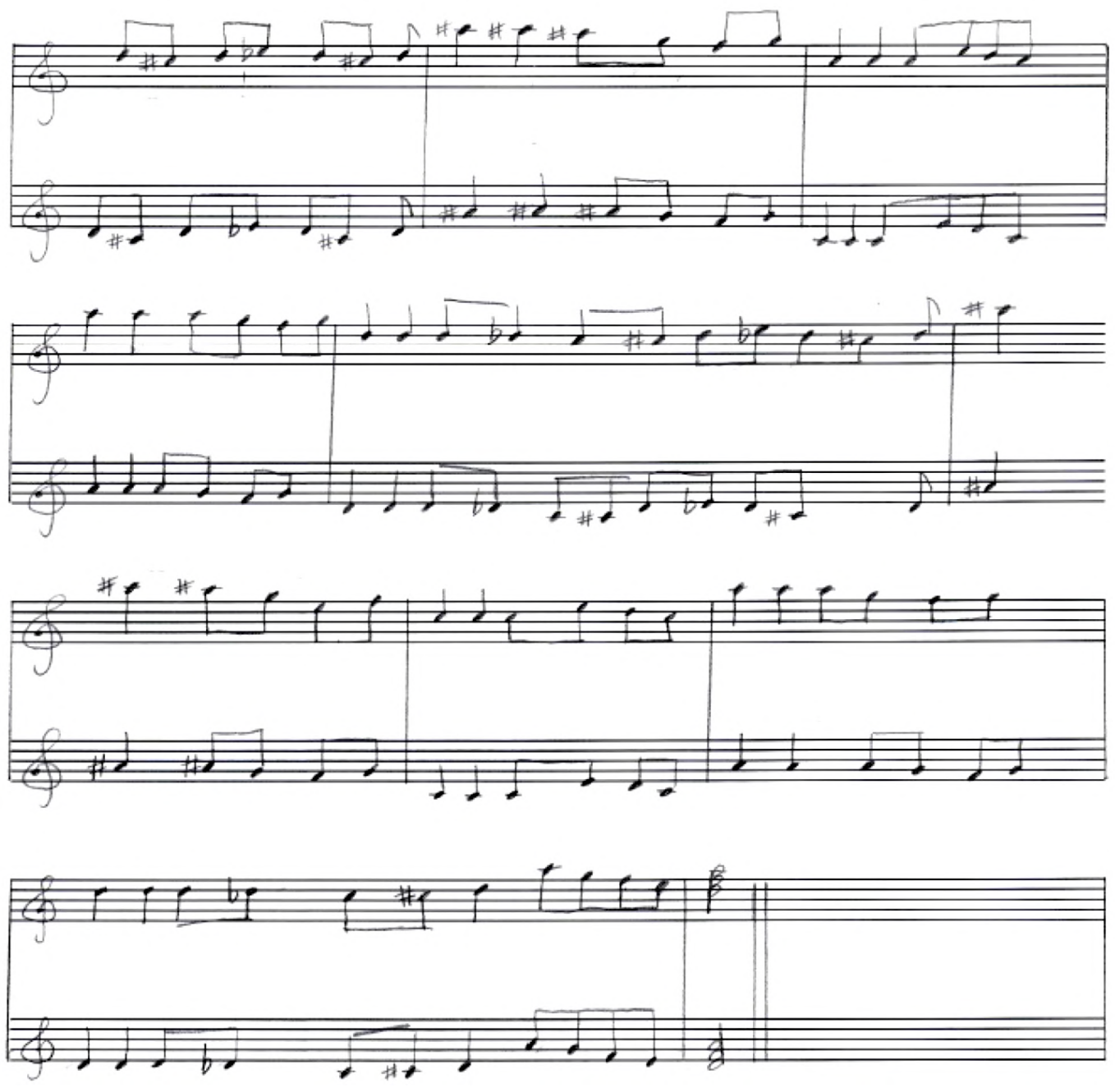

While the young composers (pupils 7-8) were writing the fourth piece, Musical changes (Fig. 6), and facing the difficulty of putting together different ideas/materials, Zavala suggested to place the ideas side by side. This compositional thinking suited the title of the work and the composer pupils said they took the title from the assembly procedure adopted "because there is no logical thread, but continuous changes”. Here the pupils' compositional approach raises some key points. In the first bar only one beam connects the first eight notes, instead of two or four beams. This indicates phrasing, and it is a practise often used nowadays to show more clearly musical ideas that music writing software programs usually standardise. Thanks to handwriting, pupils instinctively beamed 
all the flagged notes. In contrast, and logically, when isolated notes appear, the composers showed that they didn't want to play them with one hand but with alternate hands.

Fig. 6-Musical Changes
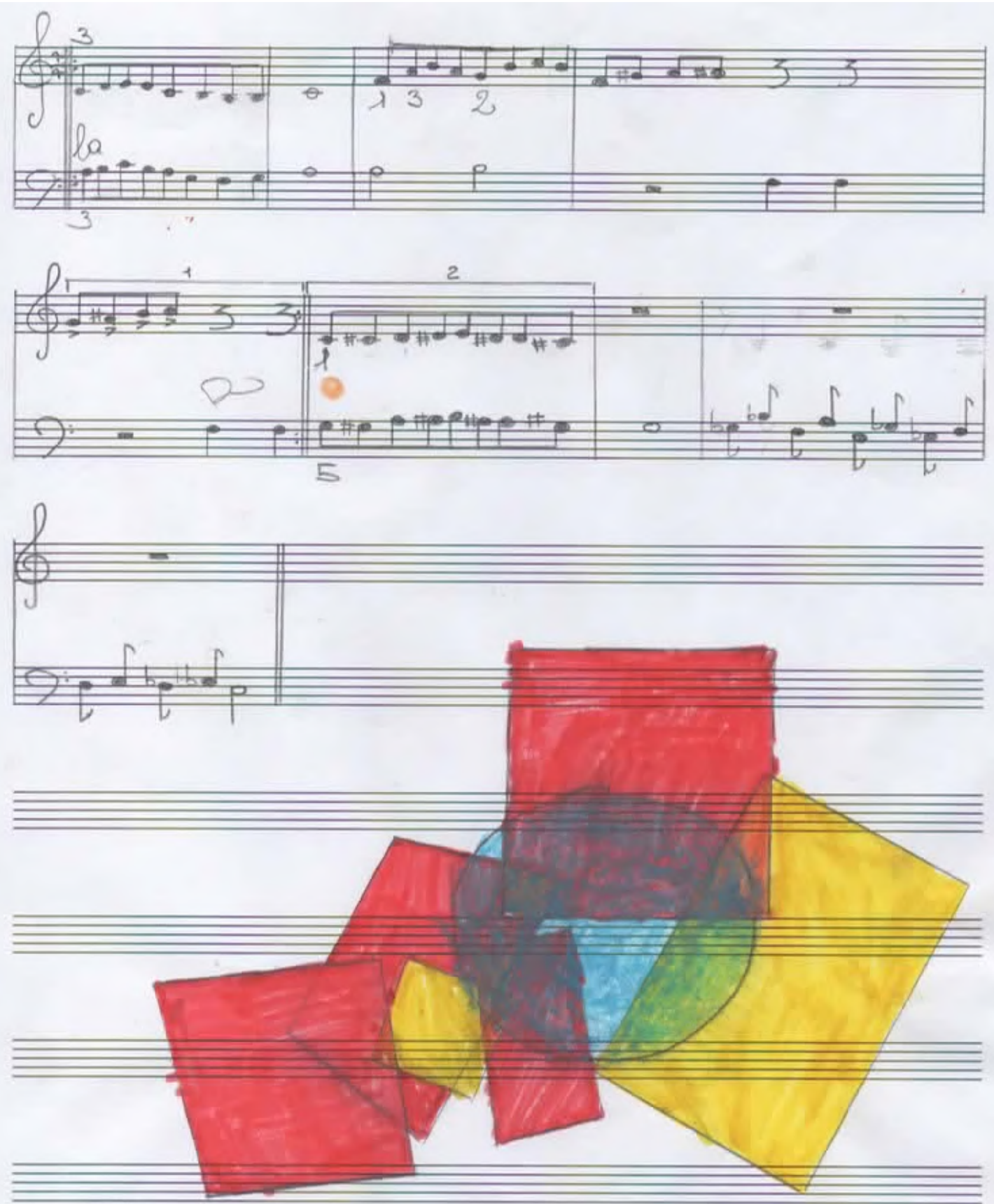

The last piece, Nuvola nera (Black Cloud) was previously written for piano and then 'perfected' and adapted to the toy piano during the workshop (Fig. 7). The composer (pupil 3, not a pair this time) was the pupil who had performed the Duvernoy's piece and the reference to this source of 
inspiration is clear in the texture's waving melody and simple accompaniment of long chords. The pupil chose the title "because it is a 'dark' song” and she was the only one who conveyed personal and emotional content in her piece.

Fig. 7 - Nuvola nera (Black Cloud).

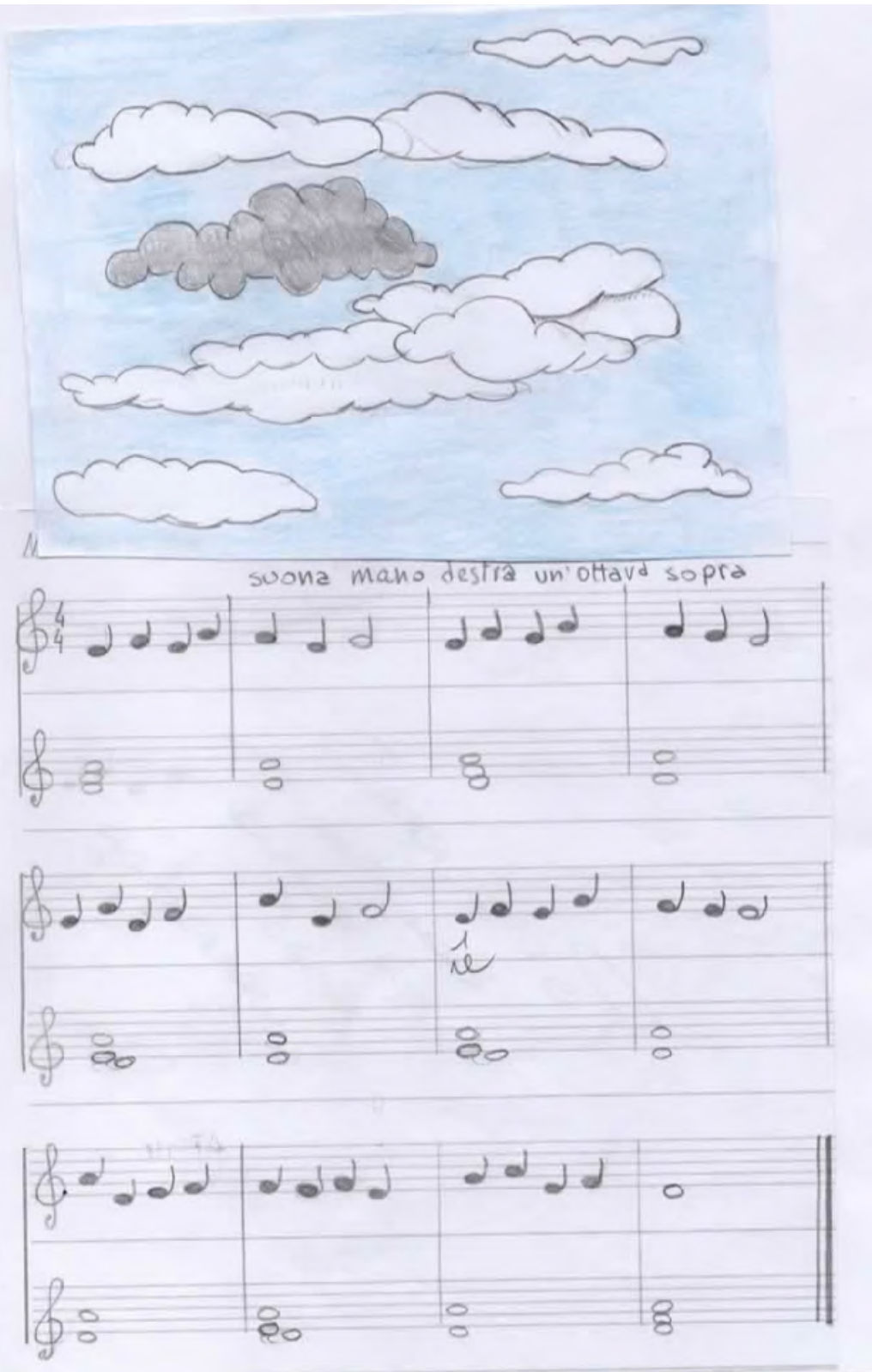

As a last activity, an improvisation session, named a Crazy Improvisation, gathered all participants together in the music room of Villa Bernasconi Museum, where we moved to on the second day. Once the rehearsal started, Zavala suggested the pupils use very simple elements, such as: small patterns of sounds that may comprise two notes and changing octaves; rhythmic patterns played 
with three black keys; four black keys freely played. She emphasised a gestural approach in conducting, with the aim of encouraging pupils to handle the toy piano freely while following her signals and listening to each other.

At the end of the second day, we invited the participants to give a title to the two-day experience. During a brainstorming session, some one-sentence titles arose: "It is not a toy piano!" (pupil 6), "Extraordinary emotion in its small size" (pupil 1), "Even the smallest are important" (pupil 7) and finally "It is not a toy!" (pupil 4). These statements highlight that the instrument is not a 'miniature real piano'; that it can be a means of expression and that they found symbolic aspects in it; and that it is more than a simple plaything, despite its external shape. Although, when searching for a title, pupils focused their attention on the instrument and not on the activity of composing, the importance of the creative work they carried out on the toy piano is implicit in what they said, highlighting the toy piano as a 'true instrument' (It is not a toy!).

\section{Personal considerations on the toy piano composition workshop}

My first aim in inviting Mercedes Zavala to hold this workshop at the school where I teach was to allow pupils to experience the toy piano in a creative way, not just to play it, and to observe how it was perceived by the young composers. Also, to understand if and how the making of a didactic process, such as the one carried out, could contribute to a wider discussion regarding the growing interest in, perception and consideration of, the toy piano.

To answer these questions, I will begin by looking back at the current debate on new classical music. One view, strongly connected with the toy piano, concerns the interest in self-limitation of pitch and other compositional materials. Considering this issue within a broader sociological context, Cage's assertion "There seemed to me to be no truth, no good, in anything big in society" (1959, p. 117), which refers to the times when he wrote his Suite for Toy piano (1948) after the Second World War, is brought into sharper musical focus by Kyle Gann (2005) who observes that the idea of pitch limitation was in the air from this time:

In 1950, Elliott Carter employed extreme pitch limitations in his Eight Etudes and a Fantasy, using only a D Major triad in the Third Etude and only the pitch $G$ in the Seventh. European works on one pitch were written by Witold Lutoslawski and Giacinto 
Scelsi. Those may have been isolated experiments, but in 1960 La Monte Young wrote a piece using two pitches: B and F\#, "to be held for a long time." In 1966 Steve Reich wrote Piano Phase using five pitches. Three years later, Philip Glass produced Music in Fifths using only seven pitches, five in each hand with three overlaps. [...] Perhaps it was the very freedom opened up by the emancipation of dissonance and atonality that required Cage and others after him to create their own limitations. (GANN, 2005, para. 3).

Gann also matches the concept of self-limitation with the marginalised composers' condition of today, examined as a consequence of the "capitalist logic of waste and planned obsolescence" (ZIZEK, 2002, p. 6) or in Adorno's words, “the built in demand to be discarded after a short while like empty food cans" (ADORNO; HOECKNER, 1997, p. 120):

In this situation the industry faces an insoluble problem. It must arouse attention by means of the ever-new products, but this attention spells their doom. If no attention is given to the song, it cannot be sold; if attention is paid to it, there is always the possibility that people will no longer accept it, because they know it too well. This partly accounts for the constantly renewed effort to sweep the market with new products, to hound them to their graves; then to repeat the infanticidal maneuver again and again. (ADORNO, 1941, p. 39).

This is a concept to which Berthold Hoeckner returns in his insight into Adorno's theories:

The culture industry thus aims to optimize an ever-increasing cycle of commodity production and destruction. While changes in fashion are sometimes grounded in genuine sociocultural needs, most of the music produced in the ensuing style, cannot answer to these needs. Necessarily, such music is drained of musical values that may transcend the contingencies of that style. So, musical expressions that encourage the discipline of imaginative concentration, for example, will not be marketed or promoted. The more deeply satisfying and rewarding to listeners such music turns out to be, the less it is in the interest of the commercial industry to produce and promote it. With its exclusive focus on maximizing turnover through rapid-fire stylistic shifting. (HOECKNER, 2013, p. 173).

In this circumstance, if self-limitation can be a choice by composers, "the limitations of our current marginalisation as composers can be as much of a spur to our creativity as Cage's use of the toy piano was" (GANN, 2005, para. 32), so contingency and immediate obsolescence don't represent an option but a risk. This is especially so when applied to the toy piano and because of the instrument's 'symbolic ambiguity', intended as the "Coexistence of the cognitive meaning of the symbol (which can be conceptualized) and the change-processes elicited and put in motion within the contemplating and experiencing subject” (FRANKENSTEIN, 1987, p. 98). Of course, the 
possibility of making several plausible interpretations is fundamental for creative thinking, but a problem arises when composers and interpreters consider and propose the toy piano exclusively 'sub specie ludi' [under the aspect of play and playfulness]. On these terms, "the visual matters more than the aural" (TEAGUE, 1991, p. 88) and only the notion of spectacle in performance is enhanced, with the risk of relegating the toy piano to ephemeral occurrences.

It is not a total criticism as many current experiences are worthy of interest (both serious and humorous). Rather, it is a matter of continuing to maintain a critical attitude in the pluralism that pervades the current production of new music. Moreover, in response to the 'disposable attitude' culture, into which the toy piano could be easily embedded, the instrument is not a contingent event on the music scene but has a history that dates back over seventy years, without taking into consideration lesser-known experiences that preceded Cage's Suite for Toy Piano. I notice that even professional musicians rarely know the toy piano's history. Instead they often have a complacent smile when a colleague shows interest in this instrument, banishing it (and her/him) immediately into an undefined area of fun and games. But I have seen how this attitude changes when the sceptic approaches the toy piano for the first time and realises how many challenges they have to face.

It is a matter of lack of knowledge. Even though an ever-wider repertoire choice is available, an in-depth understanding will profit from increasing research and musicological monographs on the topic. For audiences, carefully planned program choices with informative program notes help listeners to not dwell only on the unconventional/curious aspects which characterise a toy piano performance, but hear the instrument as a valid sound source. But to achieve this, "composers and other program note writers might benefit from asking themselves when, where, how, and in what form each work is best communicated to different stakeholders" (BLOM; BENNETT; STEVENSON, 2016, p. 9). ${ }^{3}$

How can a composition and improvisation workshop carried out with young pupils contribute to the collective perception of the 'toy piano phenomenon'? In my opinion, all that has been said cannot be separated from a 'pedagogy in action', involving young pupils, namely the future audience. Taking into consideration pupils' composing process, it reflects the attitude of the

\footnotetext{
${ }^{3}$ About implications for program note writers and readers, and for educators see: The Composer's Program Note for Newly Written Classical Music: Content and Intentions, Diana Blom et al., 2016.
} 
professional composers towards this instrument. Composers usually convey their own languages in composing for toy piano, as pupils do when transferring the languages they know over to writing their pieces. In doing this, I observed three directions among professionals, from previous discussions on the scored repertoire for toy piano:

[...] provocation with respect to tradition (both from the composing and performing point of view); the enhancement of the instrument's symbolic aspect (childhood with its related imaginative paths) while remaining rooted in tradition; and research and electroacoustic experimentations evoked by its distinguished sound (e.g. the overtones which are louder than the fundamental pitches). (LOFFREDO, 2013, p. 82).

Focusing on the second point made above, childhood symbolism, the linguistic reference to tradition mostly depicts childhood metaphors or memories. ${ }^{4}$ In the pupils' compositions a tonal language prevailed but this was disconnected from 'memories' - avoiding associations with childhood images - a very different outcome from many adult composers writing for toy piano. The use of a traditional language, conveyed by the distinctive sound of the toy piano and without previous extra musical influences, leads 'towards the new', or better towards 'new sounds'. I mean this in the same sense as intended by Cage when, on his decision to write for toy piano, he said what he wanted was "to discover again, as though they were completely unfamiliar, the most familiar sounds" (KOSTELANETZ, 2003, p. 68-69). And it resonates with the first point made in my quote above although for the pupils, not deliberate 'provocation with respect to tradition'. This thought came to my mind after the workshop when I invited my pupils to play their pieces at the piano and one of them (pupil 1) said: "I like it this way too, but it sounds different, it almost looks like another piece". Here is a key observation on the part of the pupil - the piece was written for toy piano, and while it works on piano, it's not the same sonic experience.

What I observed during the two-day activity - and contrary to my expectations - was that pupils didn't perceive the peculiar sound of the toy piano, including the unpredictable overtones and the restricted dynamic range, as limits but as possibilities. In other words, they didn't reject the 'imperfections' but welcomed them as a distinctive feature. In fact, pupils didn't seem to give particular attention to these aspects, but when it happened, the sparkling sounds of the toy piano 
were compared by pupils to stars appearing in the sky (see Notte stellata/Starry Night; pupils 5-6). Comparisons with the real piano were initially inevitable, both being keyboard instruments, and the difficulties in mastering the clumsy mechanics of the instrument became immediately evident when they played their pieces, facing the same challenges as professional musicians. Except, they immediately moved away from the reference icon, the piano, accepting the toy piano as a new instrument to be explored. I take this as a first step which traces Cage's path, from when he wrote for toy piano as a solo instrument, before introducing it in electro-acoustic music in 1960 with Music for Amplified Toy Pianos. Consequentially, the toy piano, combined with the possibility of manipulating its sound, could be a future step for a next project/workshop, to broaden pupils' creative experience while promoting knowledge of the contemporary music compositional possibilities.

As a performer and piano teacher, to make known new musical languages and aesthetics to pupils from the early stages of their piano studies has been a constant aim of mine. Quoting myself from eleven years ago, "It is not a question of introducing this music because it is 'appreciated', but of offering significant means and programmes in a broader context” (LOFFREDO, 2009, p. 9). And the choice to involve composer Mercedes Zavala was not by chance; we collaborated on several initiatives aimed at bringing young pupils closer to contemporary classical music. For this reason, and also for our previous collaborations in projects focused on the toy piano, I invited Zavala to run the composition workshop with my pupils.

After the workshop Mercedes Zavala provided in depth descriptions and discussions on the workshop process and outcomes during two conferences - “¿En serio o enbroma? La composiciónen las primeras etapas del aprendizaje musical” (Conservatorio "Teresa Berganza”, Madrid, 28 October 2019) and "From Piano to Toy Piano: composing as a rite of passage" ("Music as Play”, toy piano festival and conference, Como, IT, 7 July 2019). Zavala intends 'rite of passage' to mean the possibility given to pupils to work creatively, for the first time, with composing, her focus during the workshop. This didn't necessarily have to be with the toy piano. According to Zavala (personal communication), the use of the toy piano in this workshop was not an end, but a means to an end (the initiation to compose). From my point of view as an observer, interested in speculating on the current and future status of the toy piano, I return to the initial questions to conclude that, in view of the experiences and outcomes discussed above, drawing further on the 
anthropological metaphor, I offer two complementary perspectives on the toy piano for consideration: toy piano 'as a rite of passage' towards new listening attitudes; and the toy piano as a 'music marker' under construction within and for our culture, open to many and contrasting interpretations, depending on how musicologists, pedagogues, composers, interpreters and the audience receive it.

\section{ACKNOWLEDGMENT}

I am grateful to Mercedes Zavala, for having shared once again with me and my pupils her knowledge and experience. I thank Alessandro, Alice, Eleonora, Jacopo, Sofia, Sophia, Vittoria and Yann for having joined me in this project. Thanks are also due to the State middle school "Don Umberto Marmori" - I.C. Cernobbio (IT) and the "Associazione Ex Alunni Scuola Media Don

Umberto Marmori”, for having supported the organization of the workshop. Special thanks are due to Villa Bernasconi Museum in Cernobbio (IT), for having hosted the second day workshop.

\section{REFERENCES}

ADORNO, W. Theodor; HOECKNER, Berthold. Dialectic of Enlightenment. Trans. John Cumming. London: Verso Classics, 1997.

. On Popular Music. Studies in Philosophy and Social Science, New York, v. 9, p. 17-48,

1941.

AGAY, Denes. La gioia del primo anno di pianoforte. Trans. Paolo Subrizi. Milan: Volontè \& Co., 2010 .

BAKER A., Elizabeth. Toyager: A Toy Piano Method. Saint Petersburg (FL): Elizabeth A. Baker, 2016.

BLOM, Diana; BENNETT, Dawn; STEVENSON, Ian. The Composer's Program Note for Newly Written Classical Music: Content and Intentions. Frontiers in Psychology, v. 7, 2016. DOI. 10.3389/fpsyg.2016.01707. Available at:

< https://www.frontiersin.org/article/10.3389/fpsyg.2016.01707>. Accessed: 1 May 2020

CAGE, John. Silence: Lectures and Writings. Middletown (CT): Wesleyan University Press, 1961. . Suite for Toy Piano. New York: Henmar Press, 1960. . Music for Amplified Toy Pianos. New York: Henmar Press, 1960.

DUVERNOY, Jean-Baptiste. Elementary Studies Op. 176. Leipzig: Edition Peters, 1903. 
FRANKENSTEIN, Carl. Between Philosophy and Psychotherapy. Jerusalem: Magnes Press, Hebrew University, 1987.

GANN, Kyle. Keynote Address for the Extensible Toy Piano. In: THE EXTENSIBLE TOY PIANO PROJECT, 1, 2005, Worcester. Available at:

<https://www.kylegann.com/ToyPianoKeynote.html>. Accessed: 5 April 2020

HOECKNER, Berthold. Apparitions: Essays on Adorno and Twentieth-Century Music.

London/New York: Routledge, 2013.

KOSTELANETZ, Richard. Conversing with Cage. London/New York: Routledge, 2003.

LOFFREDO, Antonietta. Contemporary Music in Piano Pedagogy. In: AUSTRALASIAN PIANO PEDAGOGY CONFERENCE, 9, 2009, Parramatta (AU). Available at:

<https://www.appca.com.au $>$. Accessed: 1April 2020

. The Toy Piano: Semi-Serious Icon of Serious Musical Changes [Abstract]. In: EIGHTH

BIENNIAL INTERNATIONAL CONFERENCE ON MUSIC SINCE 1900, 8, 2013,

Liverpool Hope University, p. 82.

. The Toy Piano. From the Playroom to the Concert Platform. Bologna: UT Orpheus, 2019.

TEAGUE N, Frances. Shakespeare's Speaking Properties. Bucknell University Press, 1991.

ZAVALA, Mercedes. From Piano to Toy Piano: composing as a rite of passage [Abstract]. In:

MUSIC AS PLAY FESTIVAL. THE TOY PIANO TAKES THE STAGE, 1, 2019, Como. Como (IT): Nodo Libri, 2019, p. 20-21.

ŽIŽEK, Slavoj. Welcome to the Desert of the Real. New York: Verso Books, 2002.

\section{ABOUT THE AUTHOR}

Antonietta Loffredo, pianist, toy pianist and musicologist, is a graduate of the Conservatorio "F.E. Dall'Abaco" in Italy and of the Conservatoire de Musique d'Issy les Moulineaux in France. She has also conducted studies in a teaching and educational context at the Department of Musicology and Cultural Heritage of Pavia University at Cremona (Specialisation school for secondary teaching, SSIS) and earned a Master of Music degree in musicology from the University of Milan with a thesis on the toy piano. Her book, The Toy Piano - From the Playroom to the Concert Platform, was published by Ut Orpheus Edizioni (Bologna, 2019). ORCID: https://orcid.org/0000-0002-4502-1804. E-mail: antoniettaloffredo36@gmail.com 